\title{
A Response to Carla Moscoso's “Populism, the Press and the Politics of Crime in Venezuela: a Review of Robert Samet's Deadline: Populism and the Press in Venezuela (Chicago: University of Chicago Press)"
}

\author{
Robert Samet ${ }^{1}$
}

Accepted: 17 August 2020 / Published online: 3 October 2020

(C) Springer Science+Business Media, LLC, part of Springer Nature 2020

It is a pleasure to receive this review of Deadline: Populism and the Press in Venezuela and to have the opportunity to engage with Carla Moscoso's insightful analysis. I'm grateful for many of the reviewer's key points, which are organized in a helpful chapter-by-chapter summary. I will return to many them later in my reply, but I want to begin by explaining what I take to be the book's broader significance.

Two decades of the tumultuous twenty-first century have undone easy assumptions about the democratizing influence of media technology. Rather than spreading liberal democracy across the globe, the political, economic, and technological openings of the late twentieth century sowed the seeds of populist revolutions. The political grounds beneath our feet are shifting; what happens next is anyone's guess. If we are to make predictions, much less act upon them, we need a conceptual framework suited to the times. That is especially true when it comes to thinking about the role of news media in political processes. So many of our normative pronouncements about what media outlets should or should not do are still playing catch up to what media outlets are actually doing.

There was no better laboratory for observing the transformation of news media in times of populist upheaval than Venezuela during the Hugo Chávez era (1999-2013). When I arrived in 2006, Venezuela was the acclaimed epicenter of the "left turn" in Latin American politics. The capital, Caracas, was home to an old and powerful private press, a robust alternative media movement, and a burgeoning state media. Digital technology and social media platforms were booming. So too were broadcast and print news outlets. Today, Caracas's incredibly diverse media ecosystem is a thing of the past, destroyed in part by the extreme political polarization that pitted supporters and opponents of the late president Hugo Chávez against one another. Much of what we are witnessing now in the USA and Europe was already on full display in Venezuela: openly partisan news outlets, selective reporting, accusations that the government was censoring the press,

This reply refers to the comment available at: https://doi.org/10.1007/s10767-020-09381-5.

Robert Samet

sametr@union.edu 
counter-accusations that the press was trying to overthrow the government, real concerns about fake news, and cynical accusations that real news was actually fake.

Theories of populism provide a robust framework for understanding the role that media plays in these polarizing times. Specifically, they allow us to observe how news outlets construct "the people" in the likeness of an aggrieved victim. That is the case I put forward in Deadline. The book starts from the premise that grievances, large and small, are what fuel populist movements, and it describes the role that news media plays in amplifying these grievances. At the heart of the story is a practice that I observed alongside crime reporters, which epitomized journalism in the Chávez era. Crime reporters focused on gathering and airing denuncias (accusations or denunciations) about all manner of wrongdoings. In Deadline, I show how this practice of public denunciation functions as the discursive scaffolding of populist mobilization; it was the observable practice though which a collective fiction, the will of the people, was brought to life. By following this practice from the ground up, we can observe the process through which populist movements take shape, and we can make more accurate predictions about where they are going.

What I take to be the book's main contribution is its description of how news media constructs the collective fiction atop which both populism and democracy rest. There is scholarly consensus that every populist movement is built in the image of "the people" (e.g., Canovan 2005; Kazin 1999; Laclau 2005; Panizza 2005). What is still missing is an adequate description of the part media play in creating this imagined community. Some might take this to be a purely academic matter, but I disagree. Predicting the fortunes of any populist movement depends on a strong understanding of its political base, how that base is formed, and how it evolves over time.

Ethnographic studies of populism are few and far between. Methodologically, ethnographers work differently than most social scientists. The resolute empiricism of participant observation - its inductive move from the specific to the general - means that ethnographers are often pigeon-holed, their theoretical contributions asked to play second fiddle to other, less grounded methods. In my introduction, I describe Deadline as a roadmap for studying the relationship between media and populism (3-4). Along with Natalia Roudakova's Losing Pravda (2017) and Reece Peck's Fox Populism (2019), it is one of a handful of recent works that provides a bottom up perspective on our current predicament. It does so from an admittedly unexpected angle.

Crime news may, at first glance, seem like an odd starting point for a book that sets out to rethink the relationship between media and populism. Charismatic leaders or grassroots activists might seem more intuitive, but this common sense is predicated on decades of forgetting. The racialized specter of crime - along with immigration and terrorism - has been the key ingredient of rightwing populism since the mid-1960s. Stuart Hall was the first scholar to recognize the pattern in his writings on authoritarian populism $(1979,1988)$. Not coincidentally, Hall's point of departure was a study of crime news and moral panics in Great Britain (Hall et al. 1978). Britain at the dawn of Thatcherism was, of course, quite different than Venezuela in the Chávez era, but in both contexts, urban crime became an object of populist mobilization and counter-mobilization.

When I began fieldwork in 2006, I was not pursing a project on populism or even crime journalism. I planned to compare how different visions of democracy translated into different 
ways of practicing journalism. Going in, I knew that Venezuela was deeply polarized between chavistas (supporters of President Chávez) and the opposition, but I did not fully appreciate the extent of the polarization until I started conducting interviews with journalists. Everythingfrom the most cataclysmic events to mundane details of personal behavior - was colored by the chavista/opposition divide. I chose to work with crime reporters because urban violence was perhaps the one thing that everyone agreed was out of control.

After a few weeks working alongside crime journalists, I became interested in their use of denuncias, a term that roughly translates as "denunciation," "accusation," or "complaint." Crime journalists saw it as their job to expose wrongdoing, and denuncias were the medium through which they operated. Some denuncias were based on painstaking investigations ala Bob Woodward and Carl Bernstein's reporting on the Watergate affair. However, most denuncias came from brief interviews with crime victims or their families, after which they were broadcast over the airwaves or published in the crime pages. These public accusations were often emotion filled, and they framed outrage over crime as part of a popular backlash. But it was not just crime journalists or the opposition who were using denuncias. The news media was flooded with denunciations of all political stripes. Anyone familiar with Latin American politics since the Cold War is likely familiar with the use of denuncias by activists and human rights defenders (e.g., Tate 2007), so I was surprised to discover that with the exception of Sylvio Waisbord's work (2000), very little had been written on the subject.

My attempt to explain the carousel of accusations and counter-accusations in Venezuela's news media led me to theories of populism and specifically to the work of Ernesto Laclau. Although I have deep reservations about many of Laclau's normative stances - especially on the relevance of class identity, but also his definition of democracy - it is nonetheless possible to separate the normative from the descriptive. Laclau effectively solved the riddle of populism, but he did so from within a theoretical tradition that is alien to many social scientists. As a result, his work is routinely misunderstood. The most egregious mistake is made by scholars who reduce "discourse" to mere words and their content (e.g., Weyland 2001). Discourse is a practice. As the ordinary language philosopher J. L. Austin reminds us, every saying is also a doing; every utterance or act of inscription is a physical speech act that can be observed, quoted, mimicked, reframed, etc. (1975).

The following thought experiment provides the clearest explanation as to why denuncias matter to the formation of populist movements.

Think of a large mass of agrarian migrants who settle in the shantytowns on the outskirts of a developing industrial city. Problems of housing arise and the group of people requests some kind of solution from the local authorities. Here we have a demand, which is perhaps only a request. If the demand is satisfied, that is the end of the matter; but if it is not, people can start to perceive that their neighbors have other, equally unsatisfied demands - problems with water, health, schooling, and so on. If the situation remains unchanged for some time, there is an accumulation of unfulfilled demands and an increasing inability for the institutional system to absorb them in a differential way and an equivalential relationship is established between them. (Laclau 2005: 73) 
Denuncias channel unfulfilled demands. Media is the primary institution through which demands are broadcast, yet media is largely absent from Laclau's theory of populist mobilization. Starting with denuncias gives us the closest thing we have to a litmus test of Laclau's ideas, but it also allows them to be reformulated based on close observation of the discursive practices that he hypothesizes. That is one way of reading Chapters 5-8 of Deadline so that they add up to something more than a series of observations about news coverage of crime in Venezuela. Chapter 5 is about the role that media plays in political polarization or the formation of an external frontier that distinguishes allies from enemies. Chapter 6 looks at denuncias as an articulating practice through which chains of equivalence are formed that link otherwise disparate grievances. Chapter 7 looks at different ways the popular will can be mobilized, and it identifies repetition (performativity) as the key mechanism through which denuncias operate. Chapter 8 tackles the principle of popular sovereignty as the underlying logic that animates both populism and democracy, a point that Laclau recognized but also obscured.

Deadline describes crime news as a conduit through which the popular will is produced: it channels demands for vengeance or protection via a stream of denuncias, accusations, and callouts; it frames these demands in the name of victims and their families; it depicts crime victims as representatives of the sovereign people; and it depicts the victimizers - the criminals, the corrupt cops, the weak politicians - as enemies of the people. All of this is overlaid with racialized and economic assumptions that map directly onto long histories of oppression. The people most likely to be cast in the role of criminals were poor and working-class people of color from the urban popular sectors. This was the group most closely associated with chavismo and the Bolivarian Revolution. All of this fits the pattern of rightwing populism that Stuart Hall identified. Today, these tactics are brazenly exploited by the likes of Jair Bolsonaro, Victor Orban, and Donald Trump. How then to explain the fact that Nicolás Maduro, heir to arguably the most successful left movement of the twenty-first century, also took up the gauntlet of punitive populism?

\section{$* * *$}

Ethnographies change in the writing, especially ethnographies that were over 10 years in the making. Deadline started off as my Ph.D. dissertation. When I began writing, I had a neat framing in which punitive populism was a strategy deployed by the opposition against the Chávez government. That was consonant with much of what I observed, but it failed on two counts. First, it ran the risk of downplaying the backlash against crime as just another mediafueled moral panic. Nothing could be further from the truth. For most of the period covered by this book, Venezuela's homicide rates were among the highest in the world and outrage was fully justified. Second, it failed to recognize the strong support for law and order policies within chavismo itself, support that President Maduro later used to legitimize a series of brutal police crackdowns. Over the past 5 years, police have killed thousands of people from the very sectors that the Bolivarian Revolution pledged to protect (UNHCHR 2019). With time and distance, I began to see this as a story of how punitive populism can emerge from within an avowedly leftist project.

I've given this extended overview in order to help frame my response to Moscoso's review and specifically three points that I believe to be most important. I am taking them out of order so as to make my reply coherent. 
First, I agree with Moscoso that moments of populist rupture usually coincide with moments of economic crisis. In Chapter 6, I describe how the economic crisis of the 1970s and 1980s helped create the conditions of possibility for the Bolivarian Revolution and Hugo Chávez. Was economic crisis a precipitating factor for Venezuela's punitive turn? Yes and no. When Nicolás Maduro assumed the presidency in 2013, he inherited what would become the worst economic crisis in modern Venezuelan history. His open embrace of mano dura was tied, in part, to economic instability as well as attempts to paper over rifts within his coalition. That said, the groundwork for Venezuela's punitive turn had already been laid. The rise of police killings, the expansion of the carceral apparatus, and the shock-and-awe policing of poor barrios - all of this was underway in Caracas long before Venezuela's petroeconomy began spiraling toward collapse. While I am not interested in dismissing the role that economics plays in the formation of populist movements, Deadline argues that we need to deepen our understanding of historical materialism beyond the purely economic.

Grievance is the material force that drives populism. I am not making an esoteric theoretical point here by grounding populism in the experience of suffering. If we assume that populism is a mechanical response to the crises of capitalism, then we risk repeating the mistakes of the Chávez administration. President Chávez's ingoing belief was that violent crime rates would fall alongside economic inequality. That did not happen. Instead, crime rates went up. By late 2005, just before I began fieldwork, it had become clear that crime was becoming a significant political issue. Instead of addressing the problem, the president and his supporters tried to paint it as a media-driven panic.

This brings me to a second cogent point that Moscoso raises-that Deadline could have shown more about the way that government-friendly news outlets covered the subject of crime. I agree. The lacuna reflects the polarized dynamics of Venezuela's public sphere. During my time on the Caracas crime beat, most state media outlets rarely covered crime news for reasons that were both ideological and pragmatic. Ideologically, crime news reinforced racial and economic stereotypes about the popular sectors that the Bolivarian Revolution was eager to overturn. Pragmatically, crime news only served to reinforce a narrative of government failure. For both of these reasons, pro-government news outlets tended to avoid crime stories. When they did turn to the topic, the coverage was propagandistic in the worst sense. Pro-government outlets played up small victories, downplayed failures (unless the failure could be set at the feet of an opposition politician), and accused their colleagues in the private press of manufacturing a crisis.

The absence of crime news from pro-government media was part of an attempt to deal with perceptions of insecurity rather than the problem itself. It dovetailed with a question that bothered many of my closest interlocutors on the crime beat. Why, we wondered, did Chávez ignore soaring crime rates? The best explanation is that a substantive solution was already out of reach by the time it had become clear that the original plan (reduce crime by reducing inequality) had failed. Security depends on justice. It depends on law abiding police, ethical judges, reasonable statutes, proportionate sentencing, accountable institutions, and equal treatment of all persons regardless of their socioeconomic status. Venezuela's justice system was in shambles from top to bottom, and it desperately needed substantive reforms, but far reaching reforms depend on the good faith of all the parties involved, which is virtually impossible to accomplish under conditions of extreme polarization. It is on this count that the opposition bears equal responsibility for Venezuela's devolution into punitive populism. Rather than affirming a commitment to democracy, their actions undermined the good faith necessary to build a functioning polity.

That brings me to one final point. The reviewer is correct to observe that populism is a recurrent feature of Latin American politics, but I am not sure we have read the same 
genealogy or take away the same lessons. It was scholars from Latin America-like Gino Germani (1978), Di Tella (1965), and Francisco Weffort (1966)—who pioneered research on populism. This first wave of research explicitly approached the phenomenon from the ground up in a way that provincialized charismatic leaders and resisted conflating populism with authoritarianism. The "rediscovery" of populism during the 1990s and early 2000s by some US and European scholars seems to have ignored this fact. It is true that caudillismo is an unfortunate habit that Latin American republics keep repeating, but populism does not begin with charismatic leadership nor does it ineluctably lead toward authoritarianism. While I completely agree with Moscoso that democracy is not reducible to popular sovereignty, neither is it conceivable without it. Scholars who tried to imagine democracy absent popular sovereignty have been the ones most surprised by populism's inevitable return.

My disagreement is not so much with the reviewer, whose comments are generous and thorough, but with the bibliography that I suspect may stand between Deadline and many of its readers. Democracy is dangerous. Not bad, mind you, but powerful and open to different articulations. For that reason, I think it is important to avoid a reactionary response to populism even in its most authoritarian forms. Trying to stuff populism back into its box is a shortsighted strategy if you are trying to preserve democratic ideals. Those of us who want to save democracy from its excesses need to pay closer attention to democracy's discontents. We should denounce the racism, classism, and the injustice of punitive populism wherever it emerges, but we also need to understand its origins and its justifications - not in order to excuse brutality against the most vulnerable, but to counter it. For a denunciation of punitive populism to be effective, it has to tap into certain grievances and immobilize others in a way that creates its own groundswell of support. The recent success of the Black Lives Matter movement is a good example, but I would caution that there is no one-size-fits-all strategy of resistance. Popular movements follow the same general pattern, but their outcomes are determined by the specific details of history. Predicting the trajectory of any popular movement begins with a material appreciation of the grievances that animate it and the different actors that bring it to life. Media is at the heart of these processes. If we want to actually understand where news media fits in these tumultuous times, then we need to move beyond liberal platitudes about what democracy should be in favor of a more clear-eyed (but still faithful) account of what democracy actually is. That is what I hope readers will take away from Deadline.

\section{References}

Austin, J. L. (1975). How to do things with words (2nd ed.). Cambridge, MA: Harvard University Press.

Canovan, M. (2005). The people. Malden: Polity Press.

Di Tella, T. (1965). Populism and Reform in Latin America. Obstacles to change in Latin America, edited by Claudo Veliz, pp. 47-72. London: Oxford University Press.

Germani, G. (1978). Authoritarianism, fascism, and national populism. New Brunswick: Transaction Publishers. Hall, S. (1979). The great moving right show. Marxism Today, 23(1), 14-20.

Hall, S. (1988). The hard road to renewal: Thatcherism and the crisis of the left. New York: Verso.

Hall, S., Critcher, C., Jefferson, T., Clarke, J., \& Roberts, B. (1978). Policing the crisis: mugging, the state, and law and order. Hampshire: Palgrave Macmillan.

Kazin, M. (1999). The populist persuasion: an American history. Cornell University Press.

Laclau, E. (2005). On populist reason. New York: Verso.

Panizza, F. (Ed.). (2005). Populism and the mirror of democracy. New York: Verso.

Peck, R. (2019). Fox populism: branding conservatism as working class. New York: Cambridge University Press. Roudakova, N. (2017). Losing Pravda: Ethics and the Press in Post-Truth Russia. New York: Cambridge University Press. 
Tate, W. (2007). Counting the dead: the culture and politics of human rights activism in Colombia. Berkeley: University of California Press.

UNHCHR. (2019). "Report of the United Nations high commissioner for human rights on the situation of human rights in the Bolivarian Republic of Venezuela." Accessed online at https://www.ohchr. org/EN/HRBodies/HRC/RegularSessions/Session41/Documents/A_HRC_41_18.docx

Waisbord, S. (2000). Watchdog journalism in South America. New York: Columbia University Press.

Weffort, F. (1966). State and mass in Brazil. Studies in Comparative International Development, 2(12), $187-196$.

Weyland, K. (2001). Clarifying a contested concept: populism in the study of Latin American politics. Comparative Politics, 34(1), 1-22.

Publisher's Note Springer Nature remains neutral with regard to jurisdictional claims in published maps and institutional affiliations. 